\title{
Pelatihan dan Pendampingan Pembuatan Media Pembelajaran Bagi Anak Berkebutuhan Khusus di SLB Kota Tarakan
}

\author{
Roby Zulkarnain Noer, Degi Alrinda Agustina \\ Universitas Borneo Tarakan \\ robyznoer@gmail.com
}

\begin{abstract}
ABSTRAK
Pelatihan dan pendampingan pembuatan media pembelajaran bertujuan agar guru dapat mengatasi dan mereduksi permasalahan siswa yang mengalami kejenuhan dalam belajar dan kehilangan minat belajarnya. Terkait hal tersebut maka diawal tim pengabdian melakukan observasi di sekolah mitra (SLB Kota Tarakan), hasil observasi menunjukkan bahwa siswa kurang tertarik dengan media yang digunakan di sekolah, sehingga guru memiliki kesulitan dalam mengembangkan media pembelajaran yang sesuai dengan karakteristik siswa. Hal tersebut berdampak pada pemahaman pembelajaran yang rendah di sekolah. Solusi yang ditawarkan tim pengabdian adalah melaksanakan pelatihan dan pendampingan kepada guru dalam mengembangkan media pembelajaran bagi anak berkebutuhan khusus. Melalui kegiatan awal sosialisasi, pelatihan dan pendampingan, pembuatan media pembelajaran ini juga bertujuan dalam memotivasi guru dalam hal berinovasi membuat media pembelajaran yang sesuai dengan karakteristik anak berkebutuhan khusus dengan adanya program ini berhasil menumbuhkan kecakapan dan keterampilan guru dalam pembuatan media pembelajaran bagi anak berkebutuhan khusus di SLB Kota Tarakan.
\end{abstract}

Kata kunci: Media pembelajaran, Anak Berkebutuhan Khusus, Pelatihan, Pendampingan

\begin{abstract}
Training and assistance in making learning media aims for teachers to overcome and reduce the problems of students who experience boredom in learning and lose interest in learning. Related to this, at the beginning of the service team making observations at partner schools, the results showed that students were less interested in the media used in schools, so teachers had difficulties in developing learning media that matched student characteristics. This has an impact on the low understanding of learning in schools. The solution offered by the service team is to carry out training and assistance to teachers in developing learning media for children with special needs. Through the initial activities of socialization, training and mentoring, the making of learning media also aims to motivate teachers in terms of innovating to create learning media that is in accordance with the characteristics of children with special needs.

Keywords: Learning media, Children with Special Needs, Training, Mentoring
\end{abstract}




\section{PENDAHULUAN}

Media merupakan alat bantu yang dapat mempermudah proses pembelajaran. Dengan alat bantu ini hal-hal yang tidak dapat disampaikan oleh guru melalui bahasa lisan maupun kalimat dapat terwakili dengan baik, bahkan bisa jadi media mengubah posisi guru dalam mengajar. Pembelajaran pada dasarnya merupakan proses komunikasi, sehingga media yang digunakan dalam proses pembelajaran disebut media pembelajaran. Media yang merupakan segala bentuk dan saluran yang digunakan untuk proses penyampaian informasi atau pesan (Januszewski and Molenda, 2008). Sehingga dengan memanfaatkan media yang tepat, siswa akan lebih mudah memahami materi yang diberikan dan meningkatkan ketertarikan terhadap pembelajaran. Selain beberapa keuntungan penggunaan media diatas, masih banyak manfaat yang dapat diperoleh. Menurut Midun dalam Asyhar (2011) diantaranya sebagai berikut.

1. Memperluas cakrawala sajian materi pembelajaran yang diberikan di kelas seperti buku, foto dan narasumber sehingga siswa akan memiliki banyak pilihan sesuai kebutuhan dan karakteristik masing-masing.

2. Siswa akan memperoleh pengalaman yang beragam selama proses pembelajaran.

3. Memberikan pengalaman belajar yang konkret dan langsung kepada siswa

4. Menyajikan sesuatu yang sulit diadakan, dikunjungi atau dilihat oleh siswa, baik karena ukurannya yang besar, terlalu kecil atau rentang waktu prosesnya terlalu panjang

5. Memberikan informasi yang akurat dan terbaru

6. Menambahkan kemenarikan tampilan materi

7. Merangsang siswa untuk berfikir kritis

8. Meningkatkan efisiensi proses pembelajaran; dan

9. Memecahkan masalah pendidikan.

Berkaitan dengan hal tersebut, langkah awal yang dilakukan adalah observasi di sekolah mitra yaitu Sekolah Luar Biasa (SLB) Kota Tarakan. Hasil dari observasi menunjukkan bahwa siswa kurang tertarik dengan media yang digunakan di sekolah, sehingga guru mengalami kesulitan dalam mengembangkan media pembelajaran yang sesuai dengan karakteristik siswa. Upaya untuk mengatasi problematika penggunaan media pembelajaran tersebut adalah dengan kreativitas guru dan keberanian guru dalam mengidentifikasi kendala dalam mengatasi keterbatasan di sekolahnya. Tak dapat dipungkiri peran media pembelajaran memang penting sebab seluruh pengetahuan yang diperoleh didapatkan dari $75 \%$ dari melihat, $13 \%$ dari mendengar dan $12 \%$ dari mengecap, mencium dan meraba menurut Peoples 1988 dalam (Aqib, 2014).

Terkait hal tersebut maka guru bertujuan agar dapat mengatasi dan mereduksi permasalahan siswa yang mengalami bosan belajar dan kehilangan minat dalam belajarnya. Sehingga guru perlu melakukan inovasi 
sebagai bentuk upaya menekan rendahnya motivasi belajar siswa menjadi permasalahan mendasar dalam meningkatkan pembelajaran di dalam proses belajar mengajar di kelas.

Berdasarkan permasalahan yang ditemukan, maka tim Program Kemitraan bagi Masyarakat (PKM) melakukan kegiatan sosialisasi sekaligus pelatihan dan pendampingan kepada guru dalam mengembangkan media pembelajaran bagi anak berkebutuhan khusus (ABK).

Tahapan kegiatan awal adalah sosialisasi media pembelajaran, hal ini juga bertujuan memotivasi guru dalam hal berinovasi membuat media pembelajaran yang sesuai dengan karakteristik anak berkebutuhan khusus. Maka dari itu, perlu adanya kegiatan refreshment bagi guru dengan pola pelatihan dan pendampingan untuk guru terkait langkahlangkah dalam pembuatan dan penggunaan media pembelajaran. Hasil dari pelatihan dan pendampingan ini nantinya akan dituangkan ke dalam bentuk karya yang akan di gunakan dalam pembelajaran yang sesuai dengan jenjang anak kebutuhan khusus, maka dari itu pendampingan pembuatan media pembelajaran ini perlu di dukung secara konsisten agar guru mampu menghasilkan proses belajar mengajar yang berkualitas.

\section{METODE PELAKSANAAN}

Kegiatan yang dilakukan meliputi tahap persiapan, pelaksaan dan monitoring evaluasi serta tindak lanjut. Tahap persiapan terdiri dari membangun kerjasama dan observasi kegiatan awal seperti membangun kerjasama dengan pihak mitra yaitu Kepala SLB Kota Tarakan.

Setelah terjalin kerjasama, dilanjutkan dengan tahap observasi dengan melakukan observasi di kelas dan melakukan wawancara dengan guru.

Pada tahap pelaksanaan terdiri dari webinar, pelatihan dan pendampingan. Webinar dilakukan karena kegiatan dilakukan pada masa pandemi. Setelah webinar, dilanjutkan pada tahap pembuatan media pembelajaran dengan materi sebagai berikut

1. Memodifikasi Kurikulum.

2. Penyusunan Program Pembelajaran Individual (PPI)

3. Penyusunan Rancangan Produksi Media Pembelajaran (RPM).

Tahap pelaksanaan yang selanjutnya adalah melaksanakan pendampingan guru dalam pembuatan media pembelajaran yang dilakukan secara berkala.

Tahap akhir kegiatan merupakan tahapan monitoring dan evaluasi, kegiatan terutama terkait media yang dikembangkan oleh guru. Sebagai tindak lanjut adalah tahapan pembentukan kader literasi yang bertujuan agar hasil kegiatan dapat dimanfaatkan dan diimplementasikan secara berkesinambungan oleh guru-guru di sekolah. Agar lebih mudah dipahami penjabaran metode pelaksanaan kegiatan dari awal sampai akhir pelatihan dan pendampingan guru dalam pembuatan media bagi anak berkebutuhan khsusu, 
maka digambarkan dengan bagan alur kegiatan seperti di bawah ini:

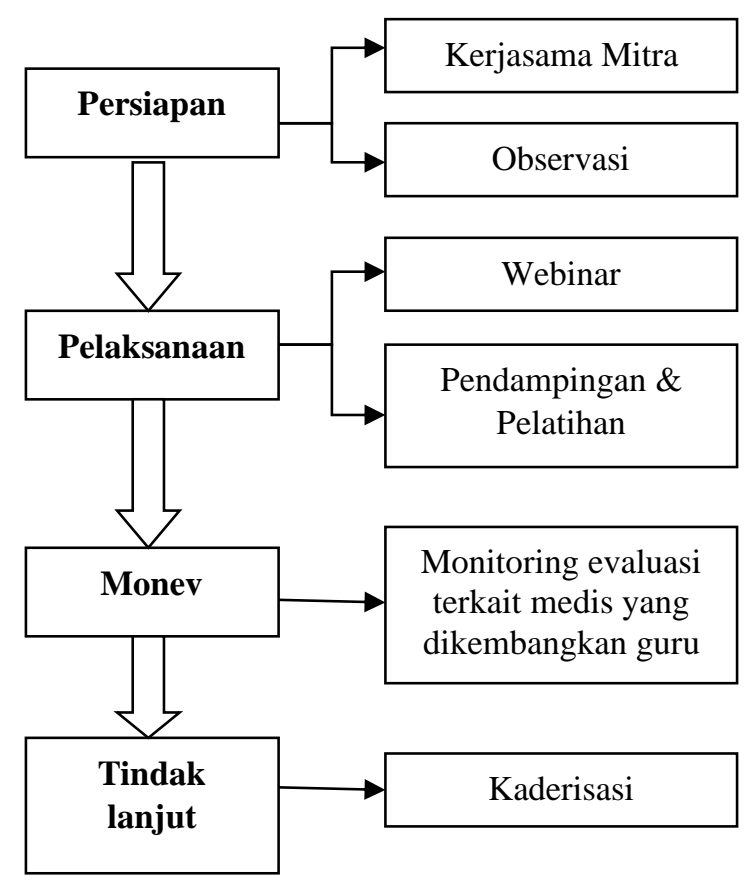

Bagan 1. Alur pelaksanaan kegiatan

\section{HASIL DAN PEMBAHASAN}

Pelaksanaan webinar dilaksanakan pada hari Rabu, 1 Juli 2020 dengan menghadirkan nara sumber antara lain: Roby Zulkarnain Noer, M.Pd dengan materi Pembelajaran Ramah Anak, Fadhlan Muchlas Abrori, M.Pd dengan Materi Ragam Media Pembelajaran, Degi Alrinda Agustina, M.Pd dengan materi Media Pembelajaran Sains bagi Siswa Sekolah Luar Biasa dan Sucahyo Mas'an Al Wahid, M.Pd dengan materi Media pembelajaran Motorik. Webinar dibuka oleh kepala sekolah SLB Kota Tarakan yaitu Ibu Sri Hastuti, S.Pd dan dihadiri oleh seluruh guru SLB Kota Tarakan. Pihak sekolah merasa senang dengan kegiatan webinar ini, alasan utama tak lain adalah untuk dapat menambah wawasan dan kreativitas guru dalam memberikan pembelajaran yang menarik bagi siswa.

Kegiatan pelatihan dilanjutkan pada hari berikutnya setelah dilaksanakan webinar. Kegiatan pertama pada pelatihan ini adalah modifikasi kurikulum. Modifikasi kurikukulum dilakukan guru dengan melakukan analisis terhadap silabus kemudian dilanjutkan pada penyusunan Rencana Pelaksanaan Pembelajaran (RPP). Kegiatan ini dilakukan selama 8 jam pelajaran. Kegiatan kedua adalah menyusun Program Pembelajaran Individu (PPI) berdasarkan analisis silabus dan RPP yang telah disusun. PPI disusun untuk menghasilkan hasil belajar yang lebih spesifik dan khas sesuai dengan karakteristik masing-masing siswa ABK. Kegiatan ini dilakukan selama 6 jam pelajaran. Kegiatan Ketiga adalah membuat Rancangan Produksi Media Pembelajaran (RPM) berdasarkan PPI yang telah disusun. Kegiatan ini dilakukan selama 6 jam pelajaran. Kegiatan ketiga adalah pendampingan Pada proses pendampingan ini tim pengabdian dan guru berdiskusi serta saling bertukar pendapat untuk media pembelajaran yang dibuat, dimana media tersebut harus sesuai dengan kebutuhan dan karakteristik siswanya.

Secara keseluruhan target luaran kegiatan pengabdian ini tercapai dengan output Media Pembelajaran Anak Berkebutuhan Khusus sebesar 65, $5 \%$ dan Peningkatan 
Kecakapan serta Keterampilan Guru dalam pembuatan Media Pembelajaran Anak Berkebutuhan Khusus di SLB Kota Tarakan sebesar $75,4 \%$. Beberapa kendala yang menyebabkan belum optimalnya perancangan media dan kecakapan guru karena kesibukan beberapa guru selaku peserta pelatihan dan pendampingan sehingga belum bisa mengikuti pelatihan secara penuh, dan juga belum memanfaatkan kegiatan pendampingan dengan baik. Harapan kedepannya pelaksanaan kegiatan pengabdian semacam ini dapat dilakukan secara konsisten dan berkelanjutan, dengan tujuan untuk melatih dan meningkatkan kreativitas guru dalam inovasi pengembangan maupun pembuatan media bagi anak $\mathrm{ABK}$.

\section{KESIMPULAN DAN SARAN}

Berdasarkan hasil monitoring dan evaluasi kegiatan PKM dengan judul Pelatihan dan pembuatan Media pembelajaran bagi Anak Berkebutuhan Khusus di Sekolah Luar Biasa
Kota Tarakan Provinsi Kalimantan Utara, mengalami peningkatan sehingga dapat dikatakan kegiatan ini berhasil menumbuhkan Kecakapan dan Keterampilan Guru dalam pembuatan Media Pembelajaran Anak Berkebutuhan Khusus di SLB Kota Tarakan.

\section{UCAPAN TERIMA KASIH}

Penulis menyampaikan terima kasih kepada SLB Kota Tarakan dan para nara sumber yang terlibat dalam kegiatan pelatihan dan pendampingan ini.

\section{DAFTAR PUSTAKA}

Asyhar, Rayandra. 2012. Kreatif Mengembangkan Media Pembelajaran. Jakarta: Referensi Jakarta.

Alan Januszewski, Molenda Michael. 2008. Education Technology A Definition with Commetary. Lawrence Erlbaum Associates Taylor \& Francis Group. New York.

Aqib, Zainal. 2014. Model-Model, Media, dan Strategi Pembelajaran Kontekstual (Inovatif). Bandung: Yrama Widya 


\section{LAMPIRAN}

Tabel 1.1 Alat Ukur Ketercapaian

\begin{tabular}{|l|l|l|}
\hline \multicolumn{1}{|c|}{ Target } & \multicolumn{1}{|c|}{ Alat Ukur } & \multicolumn{1}{c|}{ Output } \\
\hline $\begin{array}{l}\text { Pembuatan, } \\
\text { Pengembangan } \\
\text { Media } \\
\text { Pembelajaran }\end{array}$ & $\begin{array}{l}\text { Penilaian Ahli Media } \\
\text { Penilaian Ahli } \\
\text { Materi/Isi } \\
\text { Angket Respon Siswa }\end{array}$ & $\begin{array}{l}\text { Media Pembelajan Anak Berkebutuhan } \\
\text { Khusus }\end{array}$ \\
\hline $\begin{array}{l}\text { Kegiatan } \\
\text { Pelatihan dan } \\
\text { Pendampingan } \\
\begin{array}{l}\text { Guru dalam } \\
\text { pembuatan media }\end{array}\end{array}$ & $\begin{array}{l}\text { Angket Respon dari } \\
\text { guru terkait kegiatan } \\
\text { Pelatihan dan } \\
\text { pendampingan } \\
\text { pembuatan media }\end{array}$ & $\begin{array}{l}\text { Peningkatan Kecakapan dan } \\
\text { Keterampilan Guru dalam pembuatan } \\
\text { Media Pembelajaran Anak } \\
\text { Berkebutuhan Khusus, khususnya di } \\
\text { SLBKota Tarakan sebagai mitra dalam } \\
\text { kegiatan }\end{array}$ \\
\hline
\end{tabular}

Tabel 1.2 Indikator Ketercapaian Luaran

\begin{tabular}{|l|l|}
\hline \multicolumn{1}{|c|}{ Aspek } & \multicolumn{1}{c|}{ Indikator Ketercapaian } \\
\hline $\begin{array}{l}\text { Pembuatan, } \\
\text { Pengembangan } \\
\text { Media Pembelajaran }\end{array}$ & $\begin{array}{l}\text { Pengembangan Media Pembelajaran Bagi Anak Berkebutuhan } \\
\text { Khusus telah mencapai nilai sangat valid atau cukup valid sesuai } \\
\text { angket validasi dari Penilaian Ahli. }\end{array}$ \\
\hline $\begin{array}{l}\text { Kegiatan Pelatihan } \\
\text { dan Pendampingan } \\
\text { Guru dalam } \\
\text { pembuatan media }\end{array}$ & $\begin{array}{l}\text { Peningkatan Kecakapan dan Keterampilan Guru dalam pembuatan } \\
\text { Media Pembelajaran Anak Berkebutuhan Khususdikatakan } \\
\text { tercapai dengan adanya respon positif dari siswa, guru dan } \\
\text { masyarakat (Komite Sekolah)pada lingkungan sekolah yang } \\
\text { bergabung dalam kegiatan Pelatihan dan Pendampingan } \\
\text { Pembuatan Media Pembelajaran Bagi Anak Berkebutuhan Khusus. }\end{array}$ \\
\hline
\end{tabular}



Gambar 1. Webinar dan Pelatihan 